\section{Research Article}

(c) 2020 Anh et.al.. This is an open access article licensed under the Creative Commons Attribution-NonCommercial 4.o International License (https://creativecommons.org/licenses/by-nc/4.o/)

\title{
Assessing Financial Market Integration in Vietnam: A Price - Based Approach
}

\author{
Tran Thi Xuan Anh
}

\author{
Ngo Thi Hang
}

Nguyen Thi Lam Anh

State Bank of Vietnam,

Banking Academy, Vietnam

DOI: https://doi.org/10.36941/ajis-2020-0o66

\begin{abstract}
This paper investigates the existence of financial market integration between Vietnam and the region (ASEAN, ASIAN) as well as the world using price-based indicators. Our paper is the first to assess the overall integration of the Vietnam financial market based on two different datasets for different sub-capital markets, the bond market and stock market, during the period of 2009 - 2018. The empirical results show that Vietnam, compared to other countries in research, holds lower regional and international integration levels in both the bond market and the stock market, but demonstrates considerably strong signs of progressing regional and global stock market integration over the period. Especially, the absolute values estimated from the beta coefficient and beta convergence approaches for the Vietnamese stock market are larger than for the bond market, proving better convergence degree and speed of Vietnamese stock market over the bond market. These bring policymakers and regulators new thoughts and more challenges in designing appropriate policies towards the development of the financial markets in the future.
\end{abstract}

Keywords: Bond market; Convergence; Financial market integration; Price-based indicators; Stock market

\section{Introduction}

Since the 1980s the degree of financial market integration has increased significantly as a result of globalization. Many countries have deregulated the domestic financial market, dismantled foreign restrictions and improved the market-oriented economic environment. This has been accompanied by a significant increase in capital flows to developing and emerging countries (Jain \& Bhanumurthy, 2005). Financial integration is suggested to drive economic growth, boots consumption, provide investors' opportunities for portfolio diversification and higher risk-adjusted rates of return and allow financial intermediation to lower costs and "excessive" profits, thereby improving resource allocation. In spite of these merits, financial markets remain underdeveloped and are believed to face up with the pressure of certain risks, including volatility risk, contagion risk, potential crisis, (Baele et al., 2004). In this regard, it is important for policymakers to access the degrees of financial integration, each of which has implications for the domestic financial stability system, as well as the ability of the domestic economy to absorb shocks such as increased volatility in financial market returns or reversals in international capital flows. Especially, "in cases in which financial integration is pursued 
in a deliberate and methodical manner-such as in emerging countries-the progress achieved tends to be far from uniform across individual economies, as well as across the various subsectors that comprise the overall" (Park, 2013).

In the past decades, Vietnam has proactively integrated into the world at different levels. After joining the WTO in 2007, Vietnam had signed and is negotiating 16 bilateral and multilateral free trade agreements (FTAs) with 58 partners. In the 2008-2015 period, Vietnam was one of the countries implementing ASEAN commitments most seriously (the country has implemented 85-95 percent of ASEAN commitments). The current debate focuses on the degree of Vietnam financial integration because of the consequences it brings to the economy. Pursuing and reaching a financially integrated economy could support developing the whole economy but also pose some handicaps, of which, costs to sustain the financial system's stabilization, countries' rising vulnerability towards external shocks. At this juncture, a reasonable degree of market integration needs to be considered officially and seriously.

There are several ways to investigating the degree of financial integration. Baele et al. (2004) considered three categories, including Price-based measures; News-based measures and Quantitybased measures. Accordingly, Quinn, Schindler, and Toyoda (2011) developed and categorized into De-jure (based on law and regulations), De-facto measures. De-jure would present the number of legal restrictions on cross-border capital flows applicable to the economy concerned, including priceand quantity-based controls on the international movement of capital, as well as restrictions on equity holdings by nonresidents. De-facto directly reflects the degree of financial integration via accessing actual cross-border capital flows and transactions.

Several studies examined the degree of financial integration at the regional or country level. However, there is a limited research on Vietnam financial markets, which mostly concerned about the progress of Vietnamese financial market development in the ASEAN region as well as the openness of the current and capital accounts. Hence, assessing the financial market integration at both regional and international levels in Vietnam is still open for discussion.

This study's novelty is that our paper is the first to measure the overall of Vietnam's financial market integration in different market segments with price-based measures, aiming at examining: (1) whether Vietnam's financial market has gained higher integration with the regional and the international markets over time; (2) if the questionable difference in the integration state between two sub-markets of Vietnam's financial market, the stock market and bond market, exists. In particular, at the country level, we provide a specific degree of integration that has not yet implemented before. We detail the convergence of bond market and stock market integration in terms of degree and speed during the period of 2009-2018. At the regional level, we compare Vietnam with other ASEAN and even Asian countries. Especially, we first evaluate the integration of Vietnam's financial market at the global level which provides an interesting view of a country with a unique economic-socio structure who is in a transition from industrial policies to a market economy.

The results not only express the current state of financial integration but also help to clearly define the coming stages of the integration process and design appropriate policy descriptions for successful, effective future financial integration.

In the next section, we provide some review of existing literature with their results on the degree of financial market integration across regions. Section 3 deals with the hypotheses development for our study. Section 4 introduces the methodology we use in this paper to measure the degree of Vietnam financial market integration. The results of the study are illustrated in Section 5 and Section 6 concludes.

\section{Literature Review}

\subsection{The Theoretical Framework}

Various concepts of financial market integration have been developed in the literature. One of the 
most popular concepts is provided by Llewellyn (1980): "the occurrence of three forces: the equality and co-movement of interest rates, the equilibrating movement of exchange rates, and the transfer of aggregate money across countries". In addition, Marston (1995) considers the two components of capital market integration: national market deregulation and capital flow liberalization.

Some other concepts look at the relationship between risk and return of various assets. Akdogan (1995) considers a financial market to be integrated if no differential risk premium exists for identical or similar financial instruments traded at different locations. Similarly, according to Bekaert and Harvey (1995), markets are integrated completely if "assets with the same risk have identical expected return irrespective of the market".

Baele et al. (2004), Economic Commission for Africa (2008), and Stavarek et al. (2011) summarize four main benefits of financial integration: more opportunities for risk diversification and risk sharing, better capital allocation, fostering financial development, and leading to higher economic growth. Regarding risk sharing, according to Baele et al. (2004), integration allows firms that face credit constrains to have better access to broader capital and financial markets. Furthermore, through risk-sharing, financial integration promotes portfolio diversification and the sharing of idiosyncratic risk across regions due to the development of new financial instruments (Staverek et al., 2011). The second benefit of financial integration is better capital allocation. Financial integration allows firms to have wider access to financial resources and investment opportunities, which leads to more efficiently pooled and processed information, and efficient allocation of capital (Kalemli-Ozcan and Manganelli, 2008). In addition to the benefits of better risk-sharing and capital allocation, the opening of the international capital market is also a factor that fosters economic growth by generating capital flows from capital-abundant markets to capital-scarce markets. Finally, financial integration helps to boost financial development by removing financial barriers, creating increased competition with lower-cost foreign intermediaries, reducing the cost of financial services for countries with less developed financial systems (Jappelli and Pagano, 2008).

In addition to the potential benefits, there are also costs concerning financial integration. Edison et al. (2002), Baele et al. (2004), ECB (2010) and many other authors mention the following significant costs of financial integration: (1) higher degree of capital flow concentration to a small number of recipient countries, leading to lack of access to financing for small countries; (2) misallocation of domestic capital flows, which may exacerbate pre-existing domestic distortions and hamper economic growth; (3) loss of macroeconomic stability due to rapid monetary expansion, inflationary pressures, real exchange rate appreciation, and widening current account deficits; (4) pro-cyclical movements in short-term capital flows as economic shocks tend to be larger and more frequent in developing countries; (5) high degree of capital flows volatility, which leads to herding and contagion effects when economic shocks within a particular country are not fully understood; and (6) risk of foreign bank entry that could pressure local banks to merge, which creates banks that could be "too big to fail" or "too political to fail".

\subsection{Empirical literature on financial market integration}

A numerous number of financial market integration measures, as aforementioned, could be grouped into De-jure (based on law and regulations), De-facto measures. Compared to the later ones, the dejure measures, due to some limitations, provide little values for practical researchers and policymakers. According to Quinn et al. (2011), De-jure indicators, mainly based on binary elements, could not evaluate and reflect the direction and behavior of real capital flows in response to changes in the statutory restrictions on current-account and capital-account transactions. Besides, de-jure measures are also costly and time-consuming to reproduce for different countries. Moreover, for the case of Vietnam, while restrictions on capital account transactions have been quite stable over time, the movements of capital flows and operations in the capital markets have been seen relatively active domestically and internationally since Vietnam's joining into WTO (2007). This partly shows that applying the de-jure approach could be not a good choice for fitting integration practices into 
measuring the actual integration degree. In this regard, an alternative approach, the De facto measures - including price-based, quantity-based, and hybrid indices, are utilized. Price-based measures (beta coefficients, beta convergence) are structured mainly based on the law of one-price, assuming that if different financial markets in the region are substantially linked to each other, there are almost no price differences of similar financial products across markets driven by arbitrage transactions.

For exploiting the financial market integration, particularly in terms of different sub-markets, the bond market and stock market, price-based indicators are more suitable than the rest since their indices' creation allow us to easily access to available sources of data and examine bond markets and stock markets separately.

In the following section, the authors provide a summary of empirical studies assessing financial market integration with the support of price-based measures across regions. According to Bundoo (2017), the early empirical literature on financial market integration mainly focuses on the European Union and Asian markets. Recently, integration studies pay greater attention to African countries, the region with the least developed financial market.

The first group of studies concentrates on developed countries, including Serletis and King (1997), Aggarwal and Kyaw (2005), Berben and Jansen (2005), Bley (2009), Rua and Nunes (2009), Mylonidis and Kollias (2010), Apergis et al. (2011), Narayan et al. (2011), Berger and Pozzi (2013). The study of Aggarwal and Kyaw (2005) tests the integration level of three participating equity markets before and after the 1993 passage of NAFTA and concludes that cointegration is found only for the post-NAFTA period. The study of Narayan, Mishra, and Narayan (2011) is one of the rare studies that examine the convergence of stock markets using international data. Narayan et al. (2011) examine stock market convergence of 120 countries from 1985-2008 and only find convergence for OECD panel and Sub-Saharan African panel. Apergis, Christou, and Payne (2011) also use an international equity market sample but only find divergent behavior. The remaining studies in this group center around European countries, the US, and Japan. Most of the research found evidence of stock market integration. Many studies find increasing correlations among dominant EU countries (France or German), UK and US but find unchanged correlations for the Japanese market (Berben and Jansen, 2005; Rua and Nunes, 2009; Mylonidis and Kollias, 2010; Berger and Ponzi, 2013). On the contrary, using the cointegration approach, Serletis and King (1997) discover that during the 1971-1992 period, although the link between 1o EU stock markets has been strengthening but market convergence is still in the process of achieving. Furthermore, Bley (2009) examines EU stock markets from 1998-2006 using cointegration approach and finds evidence of the stock markets were starting to drift apart, which might be a temporary phenomenon but might question the integration expectation for the Eurozone.

The second group of studies assesses the degree of capital market integration in the African region, including Wang et al. (2003), Adjasi and Biekpe (2006), Yabara (2012), Bundoo (2017). Overall, mixed results are found for capital market integration in African countries. Adjasi and Biekpe (2006) study the links among 7 African stock markets (1997-2005) using cointegration and error-correction modeling and discover unique long-run relationships underlying African stock markets for both larger and smaller ones. Bundoo (2017) analyses stock market integration in 7 SADC (Southern African Development Community) countries from 1999-2011 using both convergence and cointegration analysis. Bundoo (2017) finds beta convergence but not sigma convergence, no cointegrating vector was identified when the US market was used as the benchmark, and week cointegration evidence was identified when the SSA index was used as the benchmark. On the other hand, Wang et al. (2003) examine the relationships among five largest emerging African stock markets and the US market from 1996-2002 and conclude that the long-run relationships and shortrun causal linkages among these markets were significantly weakened after the 1997-1998 financial crisis. Similarly, Yabara (2012) examines 4 capital markets in the East African Community from 2001 2010 and finds that capital market integration in the area is limited.

Regarding Asian markets, numerous studies measuring capital market integration levels have 
been done, including Manning (2002), Tai (2007), Awokuse, Chopra, and Bessler (2009), Yu, Fung, and Tam (2010), Rizavi, Naqvi, and Rizvi (2011), Komatsubara, Okimoto, and Tatsumi (2017), and Wahyoe (2018).

Using both convergence and cointegration analysis, Manning (2002) examines the integration level of 9 Asian countries from 1988-1999. The paper's results indicating partial convergence of the indices: two periods of convergence was found for Asian markets (1988 - 1990 and 1992 - mid-1997), and two periods of divergence was found (1990 - 1992 and during the 1997 Asian financial crisis). Using convergence analysis, Rizavi et al. (2011) examine the financial integration levels of 10 Asian economies (excluding Japan) from 1999 to 2009. Rizavi et al. (2011) reach the conclusion that increasing integration was found from 1999 to 2004, however, the integration levels started to decrease after 2004. Using cointegration analysis, Tai (2007), Awokuse et al. (2010), Yu et al. (2010) investigates Asian capital markets during different time periods, though evidence of capital market integration was found for all three studies. Tai (2007) examines whether 6 Asian emerging stock markets have become integrated into international capital markets since their announced liberalization dates. The sample period ranges from 1980 to 2001. The results from Tai's (2007) study show that the stock markets form India, Korean Philippines, Malaysia, and Thailand were not integrated from the world capital markets before the liberalization announcements, but all six markets have become fully integrated since then. Awokuse et al. (2009) investigate the interdependence among 9 Asian emerging markets and 3 major stock markets (US, UK, and Japan) from 1990 - 2002. The results indicate that the level of market integration was increasing from $1990-$ 1997, but the trend weakened during the 1997 Asian financial crisis. Awokuse et al. (2009) find that the US and Japan have the strongest influence on the Asian markets while Singapore and Thailand showed an increased influence on other markets since the 1997 crisis. Yu et al. (2010) cover 10 Asian economies from 1994-2008. Their results indicate that the equity market integration process was slowing down between 2002 and 2006, but picked up again in 2007-2008. Komatsubara et al. (2017) investigate the integration of East Asian equity markets between 1995 and 2013. The paper's results show that equity market integration among East Asian countries and China has increased substantially since 2007, whereas the level of equity market integration among East Asian countries excluding China increased significantly from 1999 to 2001. Wahyoe (2018) examines the financial integration in the Asia-Pacific region using stock market data from 9 Asian-Pacific countries from 2002-2012. Wahyoe (2018) concludes that Asia-Pacific stock markets are not fully segmented in terms of liquidity risk, which indicates the evidence of stock market integration. Furthermore, the level of stock market integration was found to be decreased during the global financial crisis.

Some other studies specialize in the ASEAN capital markets, such as Click and Plummer (2005), Henry, Olekahns, and Lakshman (2007), Phuan, Lim, and Ooi (2009), and Fry-McKibbin, Hsia, and Martin (2018). Using convergence analysis, Henry et al. (2007) measure the equity market integration in 8 ASEAN countries from 1990 - 2006. Henry et al. (2007) find strong evidence that stock returns shocks are transmitted across markets, impacting not only on stock prices but also on stock volatility. Using cointegration analysis, Click and Plummer (2005) consider the integration degree of five ASEAN stock markets from 1998 - 2002. Click and Plumer (2005) discover that the stock market in Five ASEAN countries are cointegrated but only in one cointegrating vector (out of five vectors), which indicates a weak form of cointegration. Using a similar approach, Phuan et al. (2009) examine the integration level of 5 ASEAN countries from 1986 - 1997. Phuan et al. (2009) conclude that no stock market integration was found during Singapore stock market liberalization (1986-1987), however long-run relationships have been established between ASEAN-5 stock markets when Thailand, Malaysia, and Indonesia have liberalized their stock markets (1987-1991) and after Philippines liberalization (1991-1997). The more recent study of Fry-McKibbin et al. (2018) estimates the financial integration in 7 East Asian and 10 ASEAN countries using stock returns data from 1997 2016. The empirical results show a generally increasing trend in financial integration over time, however, deviations were found during the Asian financial crisis period of 1997-1998, the US crisis in 2007-2010 and the debt crisis in the EU. The results also indicate a significant influence of the 
Chinese economy on the financial integration degree in the examined area.

In summary, the empirical literature shows mixed results for financial market integration for developed and African markets. However, most of the empirical evidence suggests an increasing trend of capital market integration in the Asian region, especially in ASEAN markets.

There is a limited number of research papers that concern the integration of Vietnam financial market. Most of relevant researches often addressed at the regional level rather than at the country level. Maharakkhaka and Kluaymai-ngarm (2018) investigate the extent and nature of the integration of Ho Chi Minh and Hanoi exchanges in Vietnam and other peers in ASEAN-5 countries, using cointegration techniques and the Granger Causality approach. The results present evidence of some degree of integration such that the gains of international investors holding a diversified portfolio in the region may have been reduced but not eliminated and policymakers and regulators will have to consider monitoring and driving the developments in the future. Piumsombun (2013) assesses the level of integration among the ASEAN capital markets, including Vietnam. By employing the techniques of beta and sigma convergence, and cointegration during the period of 2003-2013, the empirical results suggested that ASEAN capital markets are integrating, but the level of integration is quite far from complete. Kim, Kim, and Choi (2015) explain the linkage among stock markets in AsiaPacific regions by applying autoregressive (STAR) model and Granger causality test. The results showed different levels of interconnection among the Asia-Pacific stock markets. Jiang, Nie, and Monginsisi (2017) employed wavelet and Variation Modes Decomposition (VMD)-based copula estimation to study the co-movement and volatility fluctuation between ASEAN stock markets. The paper considered the establishment of ASEAN exchange based on the data from 2009-2016 and concluded that there has been a strong degree of integration and co-movement among ASEAN stock markets, except Vietnam.

Since there is limited research on Vietnam financial markets, this present study aims at exploring the degree of Vietnam financial markets and their relationship with other financial markets ASEAN. Data and methodology of the research are discussed in the next section.

\section{Methodology and Data}

\subsection{Methodology}

\subsubsection{Beta Coefficients}

ECB (2006) introduced the concept of beta coefficients, which could be utilized as a price-based measure to assess the integration levels of a country's capital market in a particular period of time. In detail, ECB (2006) believed that if a specific capital market (bond market, stock market) is in a full integration state, bond yields and stock returns should promptly respond to common news to different regional and international markets. In this regard, the following regression is employed:

$$
\Delta R_{c, t}=\alpha_{c, t}+\beta_{c, t} \Delta R_{\text {benchmark }, t}+\varepsilon_{c, t}
$$

where $\mathrm{c}$ and $\mathrm{t}$ denote country $\mathrm{c}$ and time $\mathrm{t} ; \alpha$ represents a country-varying and time-varying intercept; $\beta$ denotes a country-dependent and time-dependent beta with respect to the benchmark proxy (bond yields or stock returns); $\Delta R$ is the change in the variable values (bond yields or stock returns) in two consecutive periods

The time series of beta coefficients for a particular period of time is produced by running the aforementioned regression with a rolling window of 18 months. Beta coefficients are expected to be close to 1 which indicates a high level of capital market integration between the interested country and the region represented by the benchmark parameter.

\subsubsection{Beta-convergence}

Beta-convergence is another price-based measure of financial market integration degree developed 
by Adam et al. (2002). This measure has been afterward adopted and utilized in many studies including Piumsombun (2013), Kaijage et al. (2012), Rizavi et al. (2011), and Manning (2002). The time series of beta-convergence is obtained from estimating the beneath regression equation with the rolling window technique:

$$
\begin{aligned}
& \Delta S_{c, t}=\alpha_{c}+\beta S_{c, t-1}+\sum_{l=1}^{L} \gamma_{l} \Delta S_{c, t-l}+\varepsilon_{c t} \\
& S_{c, t}=R_{c, t}-R_{\text {benchmark }, t}
\end{aligned}
$$

where $\mathrm{c}$ and $\mathrm{t}$ denote country $\mathrm{c}$ and time $\mathrm{t} ; \alpha$ represents a country-varying and time-varying intercept; $\mathrm{R}$ is the bond yield or the stock returns, 1 denotes lag level. As for the stock market, stock return time series is derived by the following equation, where $\mathrm{P}$ denotes stock market index:

$$
R_{c, t}=\ln \left(\frac{P_{c, t}}{P_{c, t-1}}\right)
$$

As clearly addressed in Adam et al. (2002), beta-convergence measure helps to shed light on two particular issues: (i) Is there any integration between the capital market of the country in question and the region?; (ii) If yes, what is the integration speed?. Then, estimated beta coefficients are expected to be negative to prove the existence of integration. According to Rizavi et al. (2011), values of regressed beta could range from o to -2 where the value of -1 shows evidence of high speeds of convergence and integration whereas beta values of $\mathrm{o}$ and -2 state no integration. Furthermore, while values of beta coefficients falling between $o$ and -1 indicate monotonous convergence, estimated beta values recorded in the range of -1 and -2 indicate oscillating convergence.

Aside from the sign of the estimated beta coefficient, the absolute value of beta shows the convergence degree. The absolute value staying between o and 0.5 represents weak convergence and correspondingly weak integration of the capital market of the country in research with the regional market whereas the absolute value being higher than 0.5 implies strong convergence.

Besides, this study also applies some tests for diagnosing common issues of linear regression model including the Breusch-Godfrey Serial Correlation LM test with the null hypothesis stating no serial correlation problem, the Breusch-Pagan-Godgrey test (the test's null hypothesis states the presence of homoskedasticity), the CUSUM test for examining the model stability.

\subsection{Data}

In an attempt to discover the existence of capital market integration between Vietnam and the region as well as with the world in tandem with assessing the according integration speed, this paper utilizes two different datasets for different sub-capital markets, bond markets and stock markets.

Table 1: List of Countries in Research and Notations in Regression

\begin{tabular}{lccc}
\hline Country & Notation in Regression & Country & Notation in Regression \\
\hline United States & US & Singapore & SG \\
Indonesia & ID & Thailand & TL \\
Malaysia & ML & Vietnam & VN \\
Philippines & PH & & \\
\hline
\end{tabular}

Data Source: investing.com

As for bond markets, a month-end dataset of 10-year government bond yields covering the time period from August 2007 to July 2018 is collected for eight countries (Table 1 \& 2). Based on bond outstanding value of each market in Asia presented in Park (2016), of eight countries' bond markets, Indonesia's 10-year government bond yields serve as the benchmark for the ASEAN bond markets, Japan's ones represent ASIAN bond markets, and the United States' bond yields is considered as the proxy for the world bond market.

As for stock markets, this study utilizes a week-end dataset of main stock market indexes of 
various Asian stock markets for the period of 31 May 2009 to 31 July 2018 (Table 3 \& 4). In order to assess the possible occurrence of the integration between Vietnam's stock market and the regional stock market and with the whole world, this paper uses MSCI Asia Pacific Index as the benchmark index for the Asian stock market, MSCI World and S\&P Global 100 are chosen to be benchmark indexes for the international stock market.

Table 2: Descriptive Statistics for Bond Yields (Month-end Dataset)

\begin{tabular}{lcccccccc}
\hline & ID & JP & ML & PH & SG & TL & VN & US \\
\hline Mean & 8.324 & 0.748 & 3.928 & 5.736 & 2.250 & 3.409 & 8.865 & 2.637 \\
Median & 7.903 & 0.775 & 3.932 & 5.402 & 2.292 & 3.525 & 8.914 & 2.491 \\
Maximum & 17.247 & 1.760 & 4.844 & 9.661 & 3.580 & 5.990 & 17.100 & 4.594 \\
Minimum & 5.167 & -0.225 & 3.093 & 3.247 & 1.297 & 1.730 & 4.098 & 1.450 \\
Std. Dev. & 2.159 & 0.541 & 0.302 & 1.680 & 0.452 & 0.805 & 2.563 & 0.746 \\
Skewness & 1.365 & -0.052 & 0.176 & 0.474 & -0.023 & 0.267 & 0.372 & 0.535 \\
Kurtosis & 5.395 & 1.744 & 3.632 & 2.029 & 3.220 & 2.898 & 3.043 & 2.527 \\
Jarque-Bera & 72.514 & 8.744 & 2.873 & 10.126 & 0.278 & 1.625 & 3.054 & 7.526 \\
Probability & 0.000 & 0.013 & 0.238 & 0.006 & 0.870 & 0.444 & 0.217 & 0.023 \\
Observations & 132 & 132 & 132 & 132 & 132 & 132 & 132 & 132 \\
\hline
\end{tabular}

Table 3: Lists of Countries' Stock Market Indexes in Research and Notations in Regression

\begin{tabular}{llcc}
\hline \multirow{2}{*}{ Country } & \multirow{2}{*}{ Stock Market Index } & \multicolumn{2}{c}{ Notation } \\
Index & Index Return \\
\hline China & Shanghai & CN & R_CN \\
Indonesia & JKSE & ID & R_ID \\
India & S\&P BSE All cap & IN & R_IN \\
Malaysia & KLSE & ML & R_ML \\
Philippines & PSE All share & PH & R_PH \\
Singapore & STI & SG & R_SG \\
Thailand & SET & TL & R_TL \\
South Korea & KSE KOSPI & KO & R_KO \\
Japan & Nikkei 225 & JP & R_JP \\
Vietnam & HNX (Index in Hanoi Stock Exchange) & VN1 & R_VN1 \\
ASIA & VNI (Index in Ho Chi Minh Stock Exchange) & VN2 & R_VN2 \\
The World & MSCI Asia Pacific & MSCIASIA & R_MSCIA \\
& S\&P Global & MSCIWORLD & R_MSCIW \\
\hline
\end{tabular}

Data Source: investing.com

Table 4: Descriptive Statistics for Stock Market Indexes (Week-end Dataset)

\begin{tabular}{|c|c|c|c|c|c|c|c|c|c|c|c|c|c|c|}
\hline & $\mathrm{CN}$ & ID & IN & JP & KO & ML & PL & SG & TL & VN1 & $\mathrm{VN}_{2}$ & MSCIASIA & MSCIWORLD & SPGioo \\
\hline Mean & 2804.34 & 4478.83 & 7137.18 & 14487.68 & 1992.36 & 1630.97 & 6006.00 & 3072.48 & 1301.30 & $94 \cdot 52$ & 578.34 & 135.73 & 1534 . & 1419.75 \\
\hline & & 75 & & 73 & 32.69 & & & 3100.16 & & & & & & \\
\hline Maxi & 5166.35 & 6660.62 & 11493.10 & 23808.06 & 2574.76 & 1887.75 & 9041.20 & 3577.21 & 1828.88 & 214.27 & 1199.96 & 187.22 & 2248.93 & 7.56 \\
\hline Mini & 79.21 & 990.47 & 4096.30 & 8160.01 & 1383.34 & $1059 \cdot 5^{\circ}$ & 2398.30 & 2273.18 & 566.03 & 51.05 & 336.73 & 100.63 & & 6.71 \\
\hline Std. D & 546.93 & $1049 \cdot 31$ & 1939.25 & 4592.86 & 224.60 & 187.85 & 1737.90 & 255.99 & 313.08 & 33.55 & 167.26 & 16.57 & & 233.76 \\
\hline Skew & 0.64 & -0.36 & 0.56 & 0.23 & 0.31 & -0.95 & -0.47 & -0.35 & -0.60 & 1.29 & 1.59 & 0.72 & 0.17 & 0.32 \\
\hline Kurtosis & 3.95 & 2.58 & .07 & 1.68 & 3.59 & 3.27 & 1.92 & 2.66 & 2.37 & 3.92 & 5.46 & 3.37 & 2.0 & 2.39 \\
\hline \multirow[t]{2}{*}{ Observations } & 478 & 478 & 478 & 478 & 478 & 478 & 478 & 478 & 478 & 478 & $47^{8}$ & 478 & 47 & \\
\hline & R_CN & R_ID & R_IN & R_JP & R_KO & R_ML & R_PL & R_SG & R_TL & R_VNi & R_VN2 & R_MSCIASIA & R_MSCIWORLD & R_SPG10o \\
\hline Mean & $8.9 \mathrm{E}-\mathrm{O} 5$ & $2.2 \mathrm{E}-\mathrm{O} 3$ & $2.0 \mathrm{E}-\mathrm{O} 3$ & $1.8 \mathrm{E}-03$ & $1.0 \mathrm{E}-\mathrm{O} 3$ & $1.0 \mathrm{E}-\mathrm{O} 3$ & $2.3 \mathrm{E}-\mathrm{O} 3$ & $6.9 \mathrm{E}-\mathrm{O} 4$ & $2.2 \mathrm{E}-\mathrm{O} 3$ & $-9.9 \mathrm{E}-04$ & $1.4 \mathrm{E}-03$ & & & \\
\hline & $2.3 \mathrm{E}-\mathrm{O} 3$ & $3.2 \mathrm{E}-\mathrm{O} 3$ & $3.2 \mathrm{E}-\mathrm{O} 3$ & $3.4 \mathrm{E}-\mathrm{O} 3$ & $2.8 \mathrm{E}-\mathrm{O} 3$ & $2.1 \mathrm{E}-\mathrm{O} 3$ & $3.2 \mathrm{E}-\mathrm{O} 3$ & $2.0 \mathrm{E}-\mathrm{O} 3$ & $3 \cdot 7 \mathrm{E}-\mathrm{o} 3$ & $1.1 \mathrm{E}-03$ & $3.7 \mathrm{E}-03$ & & & \\
\hline Max & E-O2 & 8.7 E-o2 & $8.9 \mathrm{E}-\mathrm{O} 2$ & $9 \cdot 9 \mathrm{E}-\mathrm{O} 2$ & $7 \cdot 6 \mathrm{E}-\mathrm{O} 2$ & $4.9 \mathrm{E}-\mathrm{O} 2$ & $7 \cdot 4 \mathrm{E}-\mathrm{O} 2$ & $7.1 \mathrm{E}-\mathrm{O} 2$ & $6.2 \mathrm{E}-\mathrm{O} 2$ & $1.4 \mathrm{E}-\mathrm{O} 1$ & $1.1 \mathrm{E}-\mathrm{ol}$ & $7 \cdot 7^{1}$ & & \\
\hline Minimum & $-1.4 \mathrm{E}-01$ & -1.1 E-o1 & $-9.9 \mathrm{E}-02$ & $-1.2 \mathrm{E}-\mathrm{O} 1$ & $-9 \cdot 3 \mathrm{E}-02$ & $-5.2 \mathrm{E}-02$ & $-9.9 \mathrm{E}-02$ & $-6.3 \mathrm{E}-02$ & -7.7 E-02 & -1.7 E-O1 & $-1.2 \mathrm{E}-01$ & $-8.1 \mathrm{~F}$ & & \\
\hline & $\mathrm{oE}-\mathrm{O} 2$ & $2.2 \mathrm{E}-\mathrm{O} 2$ & $2.3 \mathrm{E}-\mathrm{O} 2$ & $2.8 \mathrm{E}-02$ & $2.0 \mathrm{E}-\mathrm{O} 2$ & $1.3 \mathrm{E}-02$ & $2.2 \mathrm{E}-\mathrm{O} 2$ & $1.8 \mathrm{E}-\mathrm{O} 2$ & $2.1 \mathrm{E}-\mathrm{O} 2$ & $3 \cdot 3 \mathrm{E}-02$ & $2.9 \mathrm{E}-02$ & & & \\
\hline ss & $-6.5 \mathrm{E}-01$ & $-6.1 \mathrm{E}-\mathrm{O} 1$ & $-1.6 \mathrm{E}-\mathrm{01}$ & $-4 \cdot 3 \mathrm{E}-\mathrm{O1}$ & $-7.2 \mathrm{E}-\mathrm{O} 1$ & $-1.9 \mathrm{E}-\mathrm{Ol}$ & $-4.2 \mathrm{E}-01$ & $-2.2 \mathrm{E}-\mathrm{O} 2$ & $-4 \cdot 5^{\mathrm{E}-01}$ & -4.9 E-O1 & $-5.4 \mathrm{E}-\mathrm{O} 1$ & -3.4 & & -01 \\
\hline & $5.9 \mathrm{E}+\mathrm{oo}$ & $6.3 \mathrm{E}+\mathrm{oo}$ & $3.9 \mathrm{E}+\mathrm{oo}$ & $4.4 \mathrm{E}+\mathrm{oo}$ & $5.5 \mathrm{E}+\mathrm{oo}$ & $4.8 \mathrm{E}+\mathrm{oo}$ & $4.5 \mathrm{E}+\mathrm{oo}$ & $4.5 \mathrm{E}+\mathrm{oo}$ & $4.5 \mathrm{E}+\mathrm{oo}$ & $6.4 \mathrm{E}+\mathrm{oo}$ & $5.0 \mathrm{E}+\mathrm{oo}$ & $4.7 \mathrm{E}+\mathrm{oo}$ & $5.5 \mathrm{E}+\mathrm{oo}$ & $5.2 \mathrm{E}+00$ \\
\hline Observations & 477 & 477 & 477 & 477 & 477 & 477 & 477 & 477 & 477 & 477 & 477 & 477 & 477 & 477 \\
\hline
\end{tabular}




\section{Empirical Findings and Discussion}

\subsection{Bond Market}

Following ECB (2006), the study employs rolling regression technique with the window size of 18 months for estimating regression equation (1) (beta coefficient approach) and (2) (beta convergence approach) above to obtain a time series of beta coefficients between a particular country's bond yields and the benchmark, which indicates the changing levels of integration between the two markets over time.

Particularly, for the case of beta convergence regressions, since the dataset is month-end, the lag lengths of the differences of specific country bond rates from the benchmark rates (lag level of variable $\Delta S_{c, t-l}$ in equation 2) are chosen by starting running the regressions with a lag order suggested by selection criteria AIC (Akaike information criterion), SC (Schwarz information criterion) and HQ (Hannan - Quinn information criterion) obtaining from testing pairs of single country bond rates and benchmark rates, then gradually eliminating lagged variables with statistically insignificant coefficients from regression models and repeating regression process. Ultimately, the chosen lag orders for beta convergence approach is tabulated in Appendix B.

\subsubsection{Beta Coefficients}

The estimated beta coefficients illustrated in Figure 1, which are expected to be close to 1, ranging from approximately - 0.5 to roughly 0.6 , indicate relatively low levels of integration between single bond market in the region - including Vietnam, Malaysia, Philippines, Singapore, and Thailand - with the region (Indonesian bond market). However, since 2014, after a stable trend during 2011-2013, the integration levels of each country's bond market with the region have tended to move up gradually, reaching the range of $0.4-0.6$, which is a positive sign for the regional integration in the bond market segment in the future. It is also obvious that Vietnam, with the estimated beta coefficients for the recent period (2014 - 2018) lying between o and 0.2, seems to experience the lowest regional integration levels compared to other bond markets.

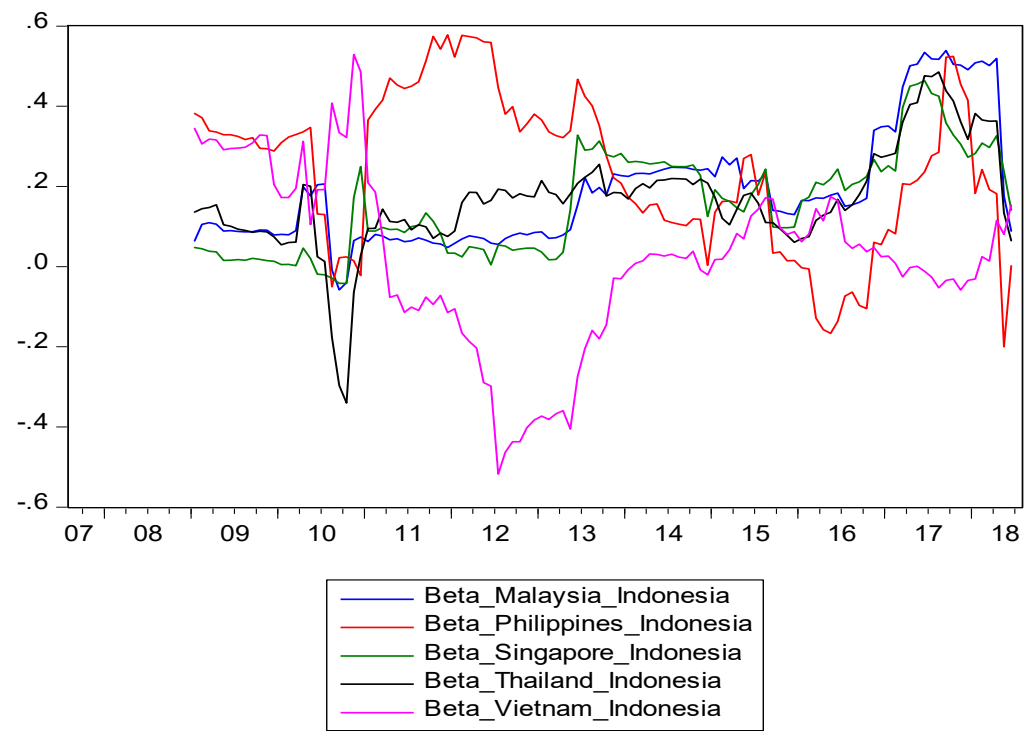

Figure 1. Beta Coefficients: Regional Bond Market Integration 
As for ASIAN's bond market, the estimated beta coefficient for the equation between Vietnam and the Asian bond market's benchmark (Japan's 10-year government bond yields) shows no statistically significant result.

\subsubsection{Beta Convergence}

As demonstrated in Figure 2, estimated beta coefficients under the beta convergence approach, which mostly stay in the range of o and -0.6 show relatively weak integration between a single ASEAN bond market with the Asia region represented by the Japanese bond market. Similar to the regression results drawn from beta coefficient approach above, Vietnam's bond market with the estimated beta coefficient being around $\mathrm{o}$ and -0.3 has still felt behind other ASEAN bond markets in terms of integration degree.

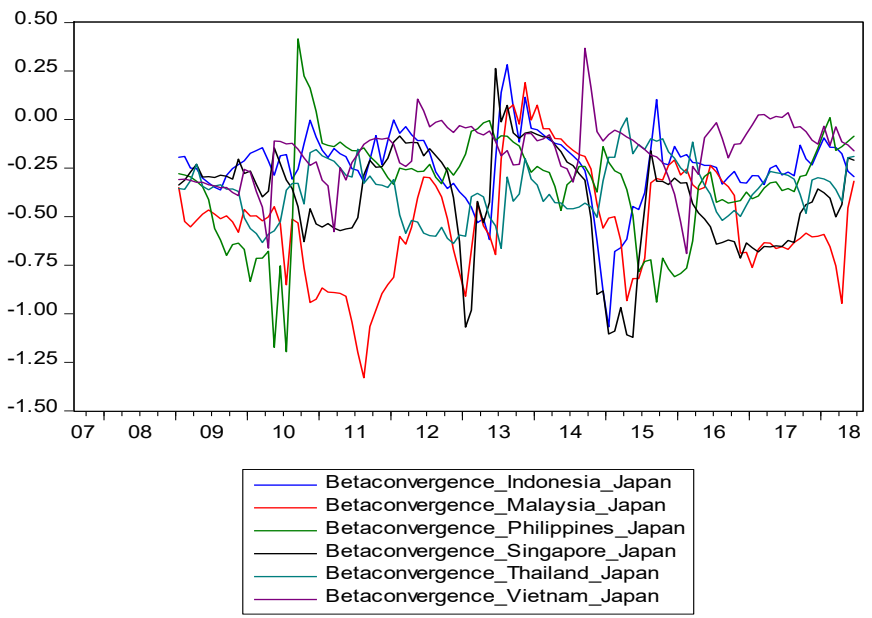

Figure 2. Beta Convergence: Regional Bond Market Integration

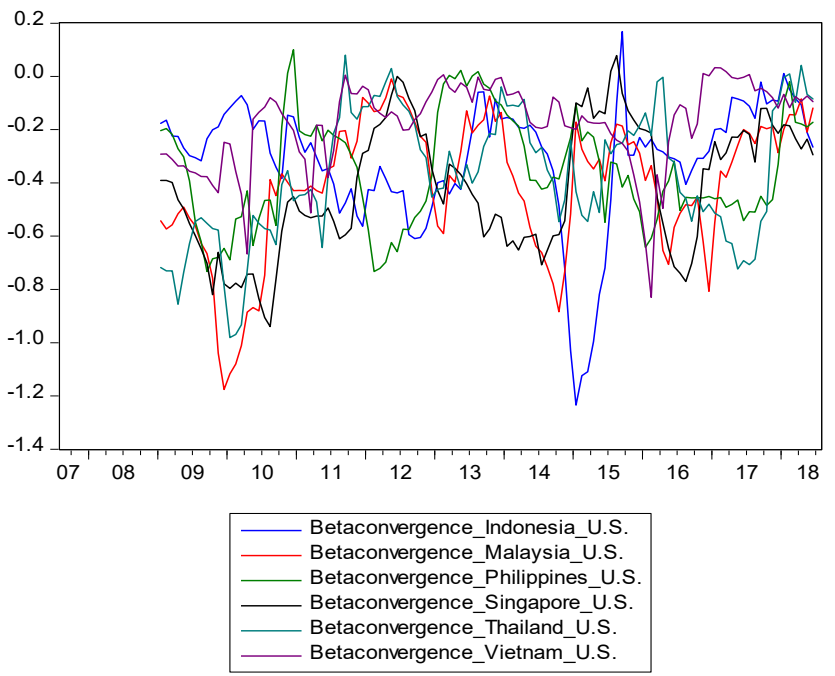

Figure 3. Beta Convergence: International Bond Market Integration 
Empirical results on the integration speed of Vietnam's bond market and other Asian countries' with the world market (the United States' 10-year government bond yields), displayed in figure 3, share similar findings to the regional case. Asian bond markets hold the low convergence and low integration speed to the world market and Vietnam has been still the weakest link among countries in research.

Estimates from beta coefficients- and beta convergence- models both prove the weak linkage between Vietnam's bond market and the region. On average, the beta coefficient of Vietnam reaches 0.02, referring that only $0.02 \%$ change in the regional bond market mirrored in Vietnam's bond market. Similarly, the beta convergence estimate of 0.22 on average indicates the speed of the Vietnamese bond market in correcting the return difference with the region is modestly $22 \%$. These findings suit the fact that the Vietnamese bond market with limited types of products and lessdiversified maturities is markedly less-developed and less-open compared to other markets in the region. More than $90 \%$ of market share is occupied by the government bond, and the main players in the market are domestic institutions (domestic and international investors just account for a relatively poor number of less than $5 \%$ ). However, with upward trends in both estimate series, we can expect the Vietnamese bond market could promisingly integrate more closely with the region in the future.

\subsection{Stock Market}

A similar technique to the bond market is applied for the case of stock markets with the window size of 72 weeks to obtain time series of beta in both beta coefficients approach and beta convergence approach. The technique of choosing lag levels in regressions of bond rates is also employed for the case of stock returns. The chosen lag lengths are provided in Appendix B.

\subsubsection{Beta Coefficients}

Different from bond market integration, estimated beta coefficients for testing stock market integration provide evidence that ASIA's stock markets have greater integration levels to the regional and international markets (Figures $4 \& 5$ ). With estimated beta value, on average, from 0.2 to 1.0, Asian stock markets' regional integration levels have remained slightly higher than the international integration ones. The paper also finds the same findings while investigating the existence of regional integration among the Asian stock market by using Japan's stock market index as a benchmark for the region instead of MSCIAsia.

When it comes to the case of Vietnam, regression results show that Vietnam's stock market has reached higher levels of regional and global integration compared to the bond market over the same period. This largely mirrors the fact that with a higher level of infrastructure development, a better investor base with the proactive participation of domestic and international investors and a rising number of institutional investors contributing to the market stability and resilience, a diversified range of products with more than 800 firms listed their shares on two main boards, and the market capitalization taking roughly $80 \%$ GDP by the end of 2018, Vietnam's stock market has attracted foreign investors' attention more than its bond market. Besides, a better liquidity feature and the recent establishment and development of derivative marking, providing foreign investors with more trading options and hedging tools, have added values to the Vietnamese stock market than the bond market.

Moreover, even though Vietnam's capital market integration has kept staying below other Asian countries' levels, similar to the bond market, both the Vietnamese stock market's regional integration levels and international integration levels have been witnessing increasing trends since 2013, which could be expected to continue in the future. 


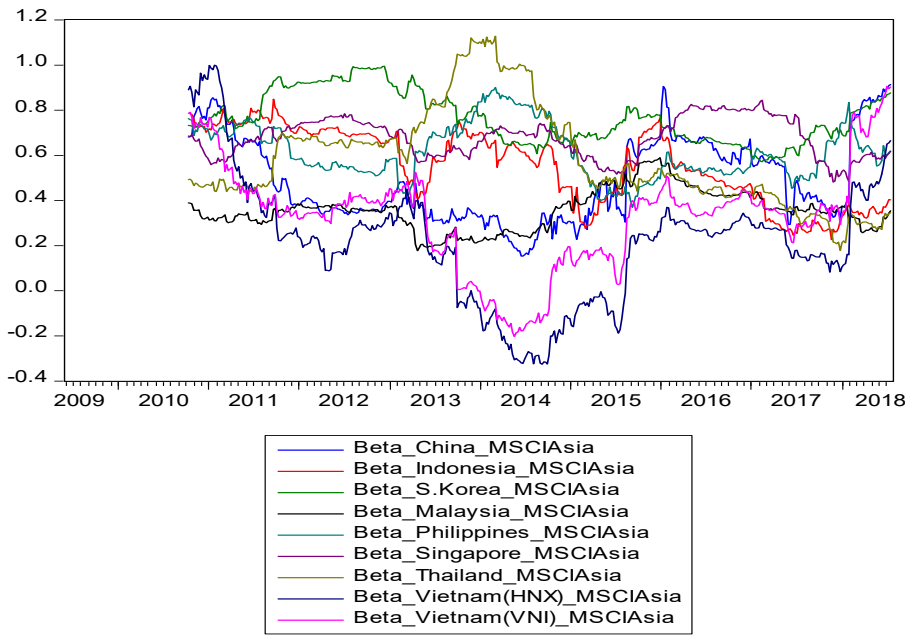

Figure 4. Beta Coefficients: Regional Stock Market Integration

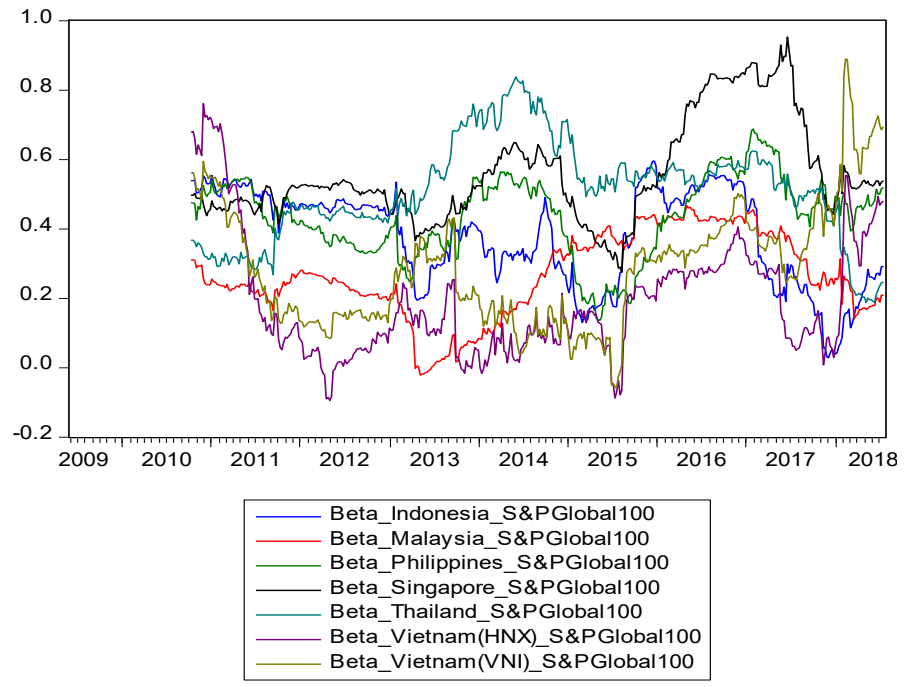

Figure 5. Beta Coefficients: International Stock Market Integration

\subsubsection{Beta Convergence}

Utilizing the beta convergence approach, this paper finds a strong and stable link between a single Asian stock market including Vietnam and the region market represented by one of the most dynamic and developed stock markets in the region, Japan's stock market (Figure 6). The same conclusion is drawn on the global stock market integration of Asian economies (Figure 7). 


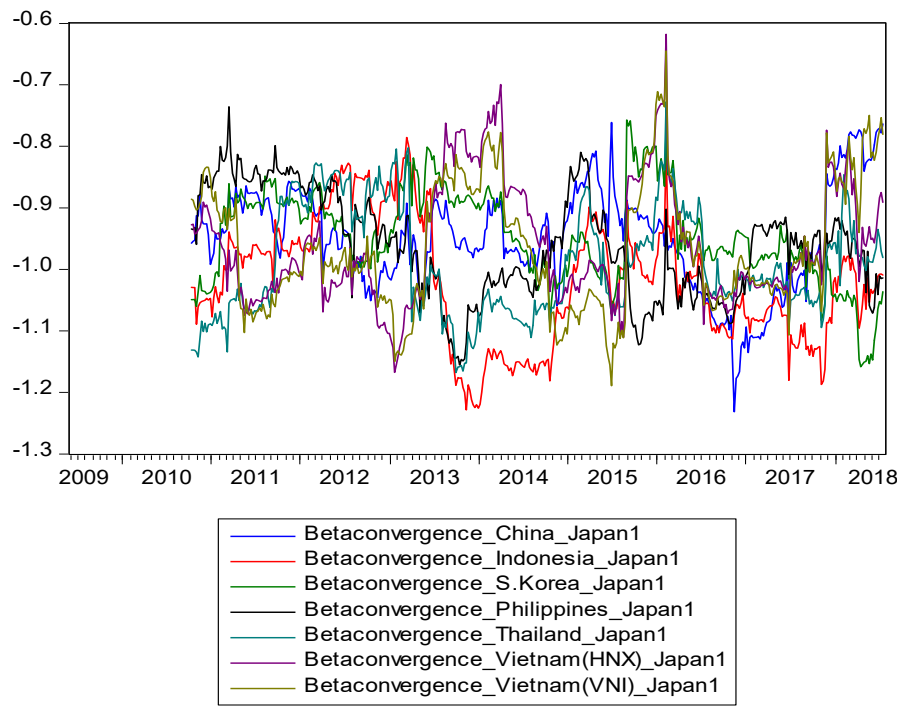

Figure 6. Beta convergence: Regional Stock Market Integration

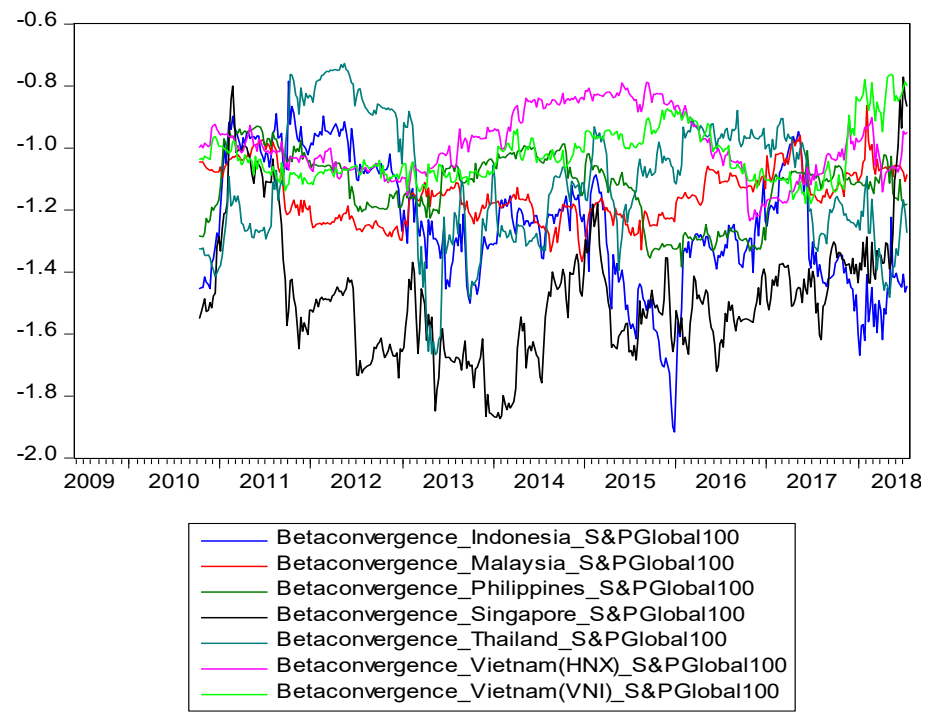

Figure 7. Beta convergence: International Stock Market Integration

In particular, as illustrated in Figure $6 \& 7$, regression results of beta convergence remain negative for the entire period of time and for different countries, implying the existence of convergence process in each country aiming at deteriorating and removing the differences between a single country's stock returns and the benchmark index. In addition, a slightly rising trend in the value of convergence parameters is captured, placing a possible increase in the global stock market integration of Asian economies. 


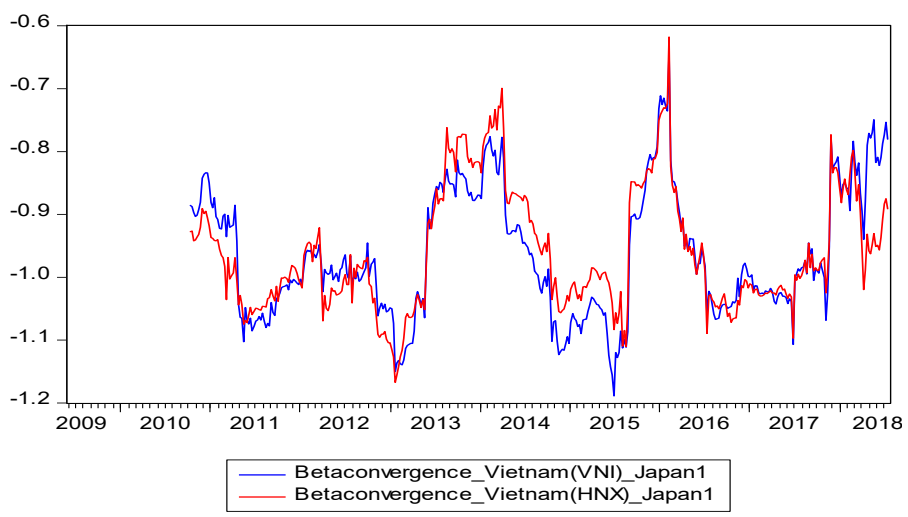

Figure 8. Beta convergence: Vietnam's stock market integration

Regarding Vietnam's stock market, although estimated beta convergence values provide considerably strong signs of regional and global stock market integration (Figure $7 \& 8$ ), their absolute values, alike beta coefficient approach, are still smaller than those of other countries, proving weaker convergence speed as well as weaker integration level.

In general, beta coefficients and beta convergence methods share the same findings on the integration level and speed of the Vietnamese stock market.

Equally important, since the samples utilized in this research cover the global financial crisis period (2007 - 2008), in addition to the aforementioned regression results, we also diagnose the existence of structural breaks. The Bai-Perron multiple breakpoint testing is employed for beta coefficient and beta convergence regressions. The results show no structural break in searching for the integration relationship between Vietnam's financial markets (bond and stock markets) and the regional's and the world's markets (Appendix C).

Further, even though the main focus of our research is applying price-based measures in illustrating the integration levels of Vietnam's financial markets with the region and the globe, we additionally use co-integration tests to see whether the long-run equilibriums between Vietnam's financial markets and regional, international markets exist. Since the co-integration analysis is only applied to non-stationary (at level) series - stock indexes, not bond rates (Appendix A) - there is no long-run relationship between Vietnam's bond market and the regional market. Co-integration results for stock indexes find no co-integration vector between Vietnam's stock market and the regional market and the international market respectively represented by MSCI Asia index and S\&P Global 100 index (Appendix D).

\section{Conclusion}

In this paper, we attempt to examine the extent of financial market integration in Vietnam. To the end, we concluded the degree of integration under two sub-capital market: the bond market and the stock market.

For measuring financial market integration, we applied price based measures to consider the convergence between Vietnam and other peers - ASEAN, ASIAN and the world market. We used beta coefficient to assess the degree of Vietnam's bond market and stock market integration at the regional and international levels. At the same time, we used beta-convergence to investigate the speed of Vietnam's capital market integration during the last ten years.

The evidence from our paper shows that Vietnam's bond market has still felt behind other ASEAN bond markets in terms of integration degree, which significantly reflects Vietnam's poor bond 
market in terms of both infrastructures, products (government bonds with major market share) with less-diversified maturities and limited types of interest rates (mainly fixed rates). Asian bond markets hold the low convergence and low integration speed to the world market, in which Vietnam has been still the weakest link among countries. Regarding Vietnam's stock market, although estimated beta convergence values provide considerably strong signs of regional and global stock market integration, their absolute values, alike the beta coefficient approach, are still smaller than those of other countries, proving weaker convergence speed as well as weaker integration level.

The estimation results additionally indicate that compared to Vietnam's stock market, the bond market seems less-developed and sluggish in the integration pathway.

These findings, based on integration measures and real data, provide policymakers and regulators in Vietnam strong evidence to consider appropriate integration policy and roadmap. In the current context of restructuring financial market in conjunction with promoting financial market integration with the regional and global markets, Vietnamese capital market regulators should consider to (i) develop bond market by encouraging the participation of corporate bonds, reliable bond rating agencies, developing new bond types, interest rates, and payment methods as well as hedging tools; (ii) as for stock market, loosening ownership room for foreign investors, strengthening derivatives market, improving investor base towards increasing the share of institutional investors.

\section{Limitations}

This research is subject to two main limitations. The first limitation concerns that regarding the assumption of the law of one price with the involvement of active arbitrage transactions under the integration environment, the indifference in prices among regional markets may not be incurred by international but domestic financial frictions, as stated in Quinn et al. (2011). Hence, to capture the whole picture of and provide accurate conclusions on the integration progress of a single country, there should be a consideration of incorporating other integration measures into research.

The second limitation of this study could be addressed in future research. That is to make the findings-based-policy recommendation of enhancing the financial market integration with the region and the world, and to incorporate the relevant risks and spillover effect of financial integration into examining integration phases, investigating promising integration threshold for Vietnam's financial market in particular conditions of economic growth, financial market development, investment environment, etc., could be tapped in more specifically.

\section{References}

Adjasi, C. K. D., \& Biekpe, N. B. (2006). Cointegration and dynamic causal links amongst African stock markets. Investment Management and Financial Innovations, 4(3), 102-119. http://hdl.handle.net/10019.1/38387

Aggarwal, R., \& Kyaw, N. A. (2005). Equity market integration in the NAFTA region: evidence from uniroot and cointegration tests. International Review of Financial Analysis, 14(4), $393 \quad-\quad 406$. https://doi.org/10.1016/j.irfa.2004.10.008

Akdogan, H. (1995). The Integration of International Capiral Markets, Edward Elgar, Brookfield.

Apergis, N., Christou, C., \& Payne, J. (2011). Political and Institutional Factors in the Convergence of International Equity Markets: Evidence from the Club Convergence and Clustering Procedure. Atlantic Economic Journal, 39(1), 7-18. https://doi.org/10.1007/s11293-010-9255-X

Awokuse, T. O., Chopra, A., \& Bessler, D. A. (2009). Structural change and international stock market interdependence: Evidence from Asian emerging markets. Economic Modelling, 26(3), 549-559. https://doi.org/10.1016/j.econmod.2008.12.001

Baele, L., Ferrando, A., Hördahl, P., Krylova, E., \& Monnet, C. (2004). Measuring Financial Integration in the Euro Area. Working Paper No.14, European Central Bank, Germany. Retrieved from https://www.ecb.europa.eu/pub/pdf/scpops/ecbocp14.pdf.

Bekaert, G., \& Harvey, C. R. (1995). Time-Varying World Market Integration. The Journal of Finance, 50 (2), 403444. https://doi.org/10.1111/j.1540-6261.1995.tbo479o.X 
Berben, R. P., \& Jansen, W. J. (2005). Comovement in international equity markets: a sectoral view. Journal of International Money Finance, 24(5), 832-857. https://doi.org/10.1016/j.jimonfin.2005.04.001

Berger, T., \& Pozzi, L. (2013). Measuring time-varying financial market integration: An unobserved components approach. Journal of Banking \& Finance, 37(2), 463-473. https://doi.org/10.1016/j.jbankfin.2012.09.015

Bley, J. (2009). European stock market integration: Fact or fiction?. Journal of International Financial Markets, Institutions and Money, 19(5), 759-776. https://doi.org/10.1016/j.intfin.2009.02.002

Bundoo, S. K. (2017). Stock market development and integration in SADC (Southern African Development Community). Review of Development Finance, 7(1), 64-72. https://doi.org/10.1016/j.rdf.2017.01.005

Click, R. W., \& Plummer, M. G. (2005). Stock market integration in ASEAN after the Asian financial crisis. Journal of Asian Economics, 16(1), 5-28. https://doi.org/10.1016/j.asieco.2004.11.018

ECB (2010). Financial integration in Europe, Frankfurt am Main: European Central Bank.

Economic Commission for Africa (2008). Assessing Regional Integration in Africa III. Towards Monetary and Financial Integration in Africa, Addis Ababa: United Nations Economic Commission for Africa. Retrieved from https://www.uneca.org/sites/default/files/PublicationFiles/aria3_eng.pdf

Edison, H. J., Levine, R., Ricci, L., \& Slok, T. (2002). International Financial Integration and Economic Growth, Journal of International Money and Finance, 21, 749-76. https://doi.org/10.3386/w9164

Fry-McKibbin, R., Hsiao, C. Y.-L., \& Martin, V. L. (2018). Global and regional financial integration in East Asia and the ASEAN. The North American Journal of Economics and Finance, 46, $202-221$. https://doi.org/10.1016/j.najef.2018.04.007

Henry, Ó.T., Olekalns, N., \& Lakshman, R. W. D. (2007). Identifying interdependencies between South-East Asian Stock market: a non-linear approach. Australian Economic Papers, 46(2), $122-135$. https://doi.org/10.1111/j.1467-8454.2007.00309.x

Jain, S., \& Bhanumurthy, N. R. (2005). Financial markets integration in India, Asia-Pacific Development Journal, 12(2), 15-32. Retrieved from https://www.unescap.org/sites/default/files/apdj12-2-2-jain.pdf

Jappelli, T., \& Pagano, M. (2008). Financial market integration under EMU”, CEPR Discussion Paper No. 7091. Retrieved from https://cepr.org/active/publications/discussion_papers/dp.php?dpno=7091

Jiang, Y., Nie, H., \& Monginsidi, J. Y. (2017). Co-movement of ASEAN stock market: new evidence from wavelet and VMD-based copula tests. Economic Modelling, $64 \quad$ (C), $384-398$. https://doi.org/10.1016/j.econmod.2017.04.012

Kalemli-Ozcan, S., \& Manganelli, S. (2008). Financial Integration and Risk Sharing: The Role of the Monetary Union. 5th European Central Banking Conference on The Euro at Ten: Lessons and Challenges, Frankfurt: ECB.

Kim, S., Kim, Y., \& Choi, M. (2015). Asia-Pacific stock market integration: new evidence by incorporating regime changes. Emerging Markets Finance and Trade, 51(4), 68-88. https://doi.org/10.1080/1540496X.2015.1026726

Komatsubara, T., Okimoto, T., \& Tatsumi, K. (2017). Dynamics of integration in East Asian equity markets. Journal of the Japanese and International Economies, 45, 37-50. https://doi.org/10.1016/j.jjie.2017.07.002

Llewellyn, D. T. (1980). International Financial Integration: The limits of Sovereignty. Wiley, New York.

Maharakkhaka, B., \& Kluaymai-ngarm, J. (2018). Capital market integration: Vietnam and its connection with ASEAN peers. ASEAN journal of Management \& Innovation, 5(1), 220-231. Retrieved from https://ajmi.stamford.edu/index.php/ajmi/article/view/215

Manning, N. (2002). Common trends and convergence? South East Asian equity markets, 1988-1999. Journal of International Money and Finance, 21(2), 183-202. https://doi.org/10.1016/so261-56o6(o1)ooo38-9

Marston, R. C. (1995). International financial integration: A study of interest differentials between the major industrial countries, Cambridge University Press, New York.

Mylonidis, N. \& Kollias, C. (2010). Dynamic European stock market convergence: evidence from rolling cointegration analaysis in the first euro-decade. Journal of Banking \& Finance, 34(9), 2056-2064. https://doi.org/10.1016/j.jbankfin.2010.01.012

Narayan, P. K., Mishra, S., \& Narayan, S. (2011). Do market capitalization and stocks traded converge? New global evidence. Journal of Banking \& Finance, 35(10), 2771-2781. https://doi.org/10.1016/j.jbankfin.2011.03.010

Park, C. Y. (2013). Asian Capital Market Integration: Theory and Evidence. Working Paper No.351. Asian Development Bank, Menila. Retrieved from http://hdl.handle.net/10419/109475

Phuan, S.-M., Lim, K.-P., \& Ooi, A.-Y. (2009). Financial Liberalization and Stock Markets Integration for Asean-5 Countries. International Business Research, 2(1). https://doi.org/10.5539/ibr.v2n1p1oo

Piumsombun, K. (2013). Assessing Asean capital market integration. Unpublished master's thesis. Copenhagen Business chool, Denmark. Retrieved from http://studenttheses.cbs.dk/xmlui/bitstream/handle/10417/4664/klongpawn_piumsombun.pdf?sequence=1 
Quinn, D., Schindler, M., \& Toyoda, A. M. (2011). Assessing Measures of Financial Openness and Integration. IMF Economic Review, 59(3), 488-522. https://doi.org/10.1057/imfer.2011.18

Rizavi S., Naqvi, B., \& Rizvi, S. (2011). Global and Regional Financial Integration of Asian Stock Markets. International Journal of Business and Social Science, 2(9), 82-93. Retrieved from https://pdfs.semanticscholar.org/7648/cac545do8d7a60346e55f99112b5864ac36e.pdf

Rua, A., \& Nunes, L. C. (2009). International comovement of stock market retursn: a wavelet analysis. Journal of Empirical Finance, 16(4), 632-639. https://doi.org/10.1016/j.jempfin.2009.02.002

Serletis, A., \& King, M. (1997). Common Stochastic Trends and Convergence of European Union Stock Markets. The Manchester School, 65(1), 44-57. https://doi.org/10.1111/1467-9957.00042

Stavárek, D., Řepková, I., \& Gajdosová, K. (2011). Theory of financial integration and achievements in the European Union. In Matoušek, R. - Stavárek, D. (eds.) Financial Integration in the European Union. (Routledge Studies in European Economy). London: Routledge. ISBN 978-0-415-69076-8.

Tai, C. S. (2007). Market integration and contagion: Evidence from Asian emerging stock and foreign exchange markets. Emerging Markets Review, 8(4), 264-283. https://doi.org/10.1016/j.ememar.2006.09.011

Wahyoe, S. (2018). Stock market integration in the Asia-Pacific region: Evidence from cointegration of liquidity risk. Economics Bulletin, AccessEcon, 38(1), 60-70. Retrieved from http://www.accessecon.com/Pubs/EB/2018/Volume38/EB-18-V38-I1-P7.pdf

Wang, Z., Yang, J., \& Bessler, D. A. (2003). Financial crisis and African stock market integration. Applied Economics Letters, 10(9), 527-533. https://doi.org/10.1080/1350485032000100198

Yabara, M. (2012). Capital Market Integration: Progress Ahead of the East African Community Monetary Union. Washington, DC: IMF. Retrieved from https://www.imf.org/external/pubs/ft/wp/2012/wp1218.pdf

Yu, I.-W., Fung, K.-P., \& Tam, C.S. (2010). Assessing financial market integration in Asia - Equity markets. Journal of Banking \& Finance, 34(12), 2874-2885. https://doi.org/10.1016/j.jbankfin.2010.02.010

\section{Appendix A: Unit root test results}

\section{Augmented Dicky Fuller Test (ADF test) for Unit root}

\begin{tabular}{|c|c|c|c|c|c|c|}
\hline \multirow[t]{2}{*}{ Variable } & \multicolumn{2}{|c|}{ ADF test } & \multicolumn{3}{|c|}{ Test critical } & \multirow[t]{2}{*}{$\begin{array}{l}\text { Conclusion } \\
\text { (At 5\% level) }\end{array}$} \\
\hline & t-stat & P_value & 1\% level & $5 \%$ level & 10\% level & \\
\hline \multicolumn{7}{|c|}{ Bond rates } \\
\hline ID & -3.803 & 0.006 & -3.481 & -2.884 & -2.579 & Stationary \\
\hline ML & -4.120 & 0.001 & -3.481 & -2.884 & -2.579 & Stationary \\
\hline $\mathrm{PH}$ & -3.579 & 0.034 & -3.481 & -2.884 & -2.579 & Stationary \\
\hline SG & -3.113 & 0.028 & -3.481 & -2.884 & -2.579 & Stationary \\
\hline TL & -4.010 & 0.011 & -4.029 & -3.444 & -3.147 & Stationary \\
\hline $\mathrm{VN}$ & -3.939 & 0.013 & -4.032 & -3.446 & -3.148 & Stationary \\
\hline $\mathrm{JP}$ & -3.635 & 0.031 & -4.029 & -3.444 & -3.147 & Stationary \\
\hline \multicolumn{7}{|c|}{ Stock Indexes } \\
\hline ID & 1.479 & 0.543 & -3.447 & -2.868 & -2.570 & Non-stationary \\
\hline ML & -2.177 & 0.215 & -3.447 & -2.868 & -2.570 & Non-stationary \\
\hline $\mathrm{PH}$ & -2.031 & 0.273 & -3.447 & -2.868 & -2.570 & Non-stationary \\
\hline SG & -2.174 & 0.216 & -3.447 & -2.868 & -2.570 & Non-stationary \\
\hline $\mathrm{TL}$ & -1.721 & 0.419 & -3.447 & -2.868 & -2.570 & Non-stationary \\
\hline VNI & -1.091 & 0.720 & -3.447 & -2.868 & -2.570 & Non-stationary \\
\hline HNX & -0.308 & 0.921 & -3.447 & -2.868 & -2.570 & Non-stationary \\
\hline MSCIA & -1.111 & 0.713 & -3.447 & -2.868 & -2.570 & Non-stationary \\
\hline SPG & -0.496 & 0.889 & -3.447 & -2.868 & -2.570 & Non-stationary \\
\hline $\mathrm{CN}$ & -1.848 & 0.357 & -3.447 & -2.868 & -2.570 & Non-stationary \\
\hline $\mathrm{KO}$ & -1.901 & 0.332 & -3.447 & -2.868 & -2.570 & Non-stationary \\
\hline \multicolumn{7}{|c|}{ Stock Indexes' Returns } \\
\hline ID & -24.965 & 0.000 & 3.444 & 2.867 & 2.569 & Stationary \\
\hline ML & -21.615 & 0.000 & 3.444 & 2.867 & 2.569 & Stationary \\
\hline $\mathrm{PH}$ & -23.868 & 0.000 & 3.444 & 2.867 & 2.569 & Stationary \\
\hline SG & -20.633 & 0.000 & 3.444 & 2.867 & 2.569 & Stationary \\
\hline $\mathrm{TL}$ & -22.452 & 0.000 & 3.444 & 2.867 & 2.569 & Stationary \\
\hline VNI & -19.802 & 0.000 & 3.444 & 2.867 & 2.569 & Stationary \\
\hline HNX & -20.437 & 0.000 & 3.444 & 2.867 & 2.569 & Stationary \\
\hline MSCIA & -22.881 & 0.000 & 3.444 & 2.867 & 2.569 & Stationary \\
\hline SPG & -21.269 & 0.000 & 3.447 & 2.869 & 2.571 & Stationary \\
\hline $\mathrm{CN}$ & -19.820 & 0.000 & 3.444 & 2.867 & 2.569 & Stationary \\
\hline $\mathrm{KO}$ & -23.479 & 0.000 & 3.444 & 2.867 & 2.569 & Stationary \\
\hline
\end{tabular}


Appendix B: Lag Orders of Beta convergence models

Panel B-1: Bond Market Integration

Table 1. Lag Order Selection by AIC, SC, HQ criteria for pairs of bond rates

\begin{tabular}{|c|c|c|c|}
\hline Lag Order Selection Results & AIC & SC & HQ \\
\hline ML \& ID & 1 & 1 & 1 \\
\hline PH \& ID & 1 & 1 & 1 \\
\hline SG \& ID & 1 & 1 & 1 \\
\hline TL \& ID & 3 & 2 & 2 \\
\hline VN \& ID & 1 & 1 & 1 \\
\hline ID \& JP & 3 & 1 & 1 \\
\hline ML \& JP & 1 & 1 & 1 \\
\hline PH \& JP & 2 & 1 & 1 \\
\hline SG \& JP & 4 & 1 & 2 \\
\hline TL \& JP & 1 & 1 & 1 \\
\hline VN \& JP & 1 & 1 & 1 \\
\hline ID \& US & 1 & 1 & 2 \\
\hline ML \& US & 1 & 1 & 1 \\
\hline PH \& US & 1 & 1 & 1 \\
\hline SG \& US & 2 & 1 & 2 \\
\hline TL \& US & 1 & 1 & 1 \\
\hline VN \& US & $-S i n g$ & 1 \\
\hline
\end{tabular}

Note: ID - Indonesia; $M L$ - Malaysia; PH - Philippines; SG - Singapore; TL - Thailand; VN - Vietnam; JP - Japan; US - United States

Table 2. Selected lag order for the variables representing the differences between country bond rates and benchmark rates

\begin{tabular}{|l|c|c|c|c|c|c|}
\hline Benchmark: Indonesia & Malaysia & Philippines & Singapore & Thailand & Vietnam & \multirow{2}{*}{} \\
\hline Lag order & $\mathbf{1}$ & $\mathrm{o}$ & $\mathrm{o}$ & 3 & $\mathrm{o}$ & \\
\hline Benchmark: Japan & Indonesia & Malaysia & Philippines & Singapore & Thailand & Vietnam \\
\hline Lag order & $\mathbf{2}$ & $\mathbf{2}$ & $\mathrm{o}$ & $\mathrm{O}$ & $\mathbf{2}$ & $\mathrm{o}$ \\
\hline Benchmark: United States & Indonesia & Malaysia & Philippines & Singapore & Thailand & Vietnam \\
\hline Lag order & $\mathbf{2}$ & $\mathbf{2}$ & $\mathbf{0}$ & $\mathbf{2}$ & $\mathbf{1}$ & $\mathrm{o}$ \\
\hline
\end{tabular}

Panel B-2: Stock Market Integration

Table 3. Lag Order Selection by AIC, SC, HQ criteria for pairs of stock returns

\begin{tabular}{|c|c|c|c|}
\hline Lag Order Selection Results & AIC & SC & HQ \\
\hline CN \& MSCIA & o & o & o \\
\hline KO \& MSCIA & 0 & 0 & 0 \\
\hline ID \& MSCIA & 1 & 0 & 1 \\
\hline ML \& MSCIA & 0 & 0 & 0 \\
\hline PH \& MSCIA & 0 & 0 & 0 \\
\hline SG \& MSCIA & 1 & 0 & 1 \\
\hline TL \& MSCIA & 0 & 0 & 0 \\
\hline VNI \& MSCIA & 1 & 0 & 0 \\
\hline HNX \& MSCIA & 1 & 0 & 1 \\
\hline CN \& SPG & 1 & 0 & 0 \\
\hline KO \& SPG & 2 & 0 & 1 \\
\hline
\end{tabular}




\begin{tabular}{|c|c|c|c|}
\hline Lag Order Selection Results & AIC & SC & HQ \\
\hline ID \& SPG & 3 & o & o \\
\hline ML \& SPG & 1 & o & o \\
\hline PH \& SPG & 1 & o & o \\
\hline SG \& SPG & 1 & 1 & 1 \\
\hline TL \& SPG & 1 & o & o \\
\hline VNI \& SGP & $\mathbf{1}$ & o & $\mathbf{1}$ \\
\hline HNX \& SGP & $\mathbf{1}$ & o & $\mathbf{1}$ \\
\hline
\end{tabular}

Table 4. Selected lag order for the variables representing the differences between country stock indexes' returns and benchmark index's returns

\begin{tabular}{|l|c|c|c|c|c|c|c|c|c|}
\hline Benchmark: MSCIAsia & CN & KO & ID & ML & PH & SG & TL & VNI (VN) & HNX (VN) \\
\hline Lag order & o & o & o & o & o & o & o & o & o \\
\hline Benchmark: S\&PGlobalıoo & CN & KO & ID & ML & PH & SG & TL & VNI (VN) & HNX (VN) \\
\hline Lag order & o & o & o & o & o & o & o & o & o \\
\hline
\end{tabular}

Note: CN - China; KO - South Korea; ID - Indonesia; ML - Malaysia; PH - Philippines; SG - Singapore; TL Thailand; VN - Vietnam; VNI \& HNX - two different stock indexes in Vietnam; MSCIA - MSCI Asia; SPG SEP Global 100

\section{Appendix C: Structural Break Test Results}

Table 5. Multiple Breakpoint Tests: Bond Rates

\begin{tabular}{|c|c|c|c|c|}
\hline Regression Equations & F-Statistic & Scaled F-Statistic & Critical Value & Conclusion \\
\hline \multicolumn{5}{|c|}{ Beta Coefficient } \\
\hline ML \& ID & 4.326 & 8.653 & 11.47 & No structural break \\
\hline PH \& ID & 3.471 & 6.942 & 11.47 & No structural break \\
\hline SG \& ID & 5.969 & 11.39 & 11.47 & No structural break \\
\hline TL \& ID & 1.699 & 3.398 & 11.47 & No structural break \\
\hline VN \& ID & 1.691 & 3.381 & 11.47 & No structural break \\
\hline \multicolumn{5}{|c|}{ Beta Convergence } \\
\hline ML \& JP & 9.514 & 28.54 & 13.98 & Break date: 2013Mo6 \\
\hline PH \& JP & 4.728 & 9.457 & 11.47 & No structural break \\
\hline SG \& JP & 11.38 & $\mathbf{2 2 . 7 6}$ & 11.47 & Break date: 2013Mo6 \\
\hline TL \& JP & $\mathbf{2 . 4 8 7}$ & 7.461 & 13.98 & No structural break \\
\hline VN \& JP & 5.280 & 10.56 & 11.47 & No structural break \\
\hline
\end{tabular}

Note: Sample: Month-end dataset from 2007 Mo8 to 2018 Mo7

Table 6. Multiple Breakpoint Tests: Stock Indexes' Returns

\begin{tabular}{|c|c|c|c|c|}
\hline Regression Equations & F-Statistic & Scaled F-Statistic & Critical Value & Conclusion \\
\hline \multicolumn{3}{|c|}{ Beta Coefficient } \\
\hline CN \& MSCIA & 3.589 & 7.179 & 11.47 & No structural break \\
\hline KO \& MSCIA & 4.977 & 9.954 & 11.47 & No structural break \\
\hline ML \& MSCIA & 4.113 & 8.225 & 11.47 & No structural break \\
\hline PL \& MSCIA & 3.770 & 7.540 & 11.47 & No structural break \\
\hline SG \& MSCIA & 1.692 & 3.384 & 11.47 & No structural break \\
\hline VN \& MSCIA & 5.023 & 10.046 & 11.47 & No structural break \\
\hline KO \& SPG & 3.948 & 7.897 & 11.47 & No structural break \\
\hline ID \& SPG & 3.421 & 6.841 & 11.47 & No structural break \\
\hline ML \& SPG & 4.237 & 8.474 & 11.47 & No structural break \\
\hline PH \& SPG & 3.5137 & 7.027 & 11.47 & No structural break \\
\hline
\end{tabular}




\begin{tabular}{|c|c|c|c|c|}
\hline Regression Equations & F-Statistic & Scaled F-Statistic & Critical Value & Conclusion \\
\hline SG \& SPG & 5.782 & 10.56 & 11.47 & No structural break \\
\hline TL \& SPG & 4.245 & 8.489 & 11.47 & No structural break \\
\hline VN \& SPG & 2.982 & 5.965 & 11.47 & No structural break \\
\hline \multicolumn{5}{|c|}{ Beta Convergence } \\
\hline CN \& JP & 4.547 & 9.094 & 11.47 & No structural break \\
\hline KO \& JP & 3.231 & 6.463 & 11.47 & No structural break \\
\hline ID \& JP & 4.891 & 9.789 & 11.47 & No structural break \\
\hline PH \& JP & 4.424 & 8.847 & 11.47 & No structural break \\
\hline SG \& JP & 4.211 & 8.422 & 11.47 & No structural break \\
\hline TL \& JP & 4.113 & 8.225 & 11.47 & No structural break \\
\hline VN \& JP & 2.111 & 4.222 & 11.47 & No structural break \\
\hline ID \& SPG & 3.463 & 6.925 & 11.47 & No structural break \\
\hline ML \& SPG & 2.762 & 5.524 & 11.47 & No structural break \\
\hline PH \& SPG & 2.999 & 5.998 & 11.47 & No structural break \\
\hline SG \& SPG & 2.250 & 4.500 & 11.47 & No structural break \\
\hline TL \& SPG & 3.463 & 6.926 & 11.47 & No structural break \\
\hline VN \& SPG & 4.342 & 8.685 & 11.47 & No structural break \\
\hline
\end{tabular}

Note: Sample: Week-end dataset from May 31, 2009 to July 22, 2018

ID - Indonesia; ML - Malaysia; PH - Philippines; SG - Singapore; TL - Thailand; VN - Vietnam; CN - China; KO - South Korea; MSCIA - MSCI Asia; SPG - SEP Global 100 